\title{
ARBITRAL TRIBUNALS FOR FOREIGN TRADE IN SOCIALIST COUNTRIES
}

\author{
KAZIMIERZ GRZXBOWSKI*
}

\section{INTRODUCTION}

The beginnings of commercial arbitration in the socialist commonwealth are directly connected with the early Soviet resort to private arbitration in commercial disputes with the capitalist countries. ${ }^{1}$ While the Soviet Union planned to expand its foreign trade, its judicial system was totally unfit to handle disputes where the law of the market, which the revolutionary state planned to abolish, provided the only valid standard for a decision. The Soviet Union was faced with the necessity either of reforming its laws and judicial system or resorting to some other method of dispute settlement acceptable to foreign traders who, as a matter of principle, were suspicious of the impartiality of Soviet courts. For the solution of its commercial disputes with foreign countries, Russia turned to private arbitration.

At no time, however, was the Soviet counterpart of commercial arbitration as practiced in the capitalist world truly private. ${ }^{2}$ Since the early days of the Soviet state the monopoly of foreign trade had been one of the important instruments of its economic policy. Business organizations established to maintain economic relations with foreign business circles were private only in the sense that they did not aspire to the status of government agencies. While in the capitalist world commercial arbitration was the creation of private interests and business organizations, in the Soviet Union it was the creation of the state.

Institutions of private commercial arbitration in the Soviet Union approximated their capitalist counterparts in the sense that they applied the law of international commerce in a spirit comparable to that of the similar institutions in the West. And yet they were never encouraged to practice arbitration as the simple, nonformalistic settlement of disputes. After long years of experience, Soviet-type com-

\footnotetext{
* Professor of Law, Duke University.

${ }^{1}$ During the Genoa Conference (April-May, r922) called by the British government to restore the economic unity of Europe, the problem of nationalization of foreign property in Russia was discusscd in connection with the question of financial assistance to Russian industries. The Russian delcgation would not recognize, however, that considerable revision of property relations as they affected trade and industrial development was necessary, and rejected a proposal for the creation of a court of arbitration to rule on the claims of foreign nationals in connection with the confiscation of their investment. Papers relating to International Economic Conference, Genoa, April-May 1922, CMd. No. i677 (I922).

"Berman, The Legal Framework of Trade Between Planned and Market Economics: The SovietAmerican Example, 24 LAW \& Contenr. ProB. 482, 494-95 (I959); Hazard, State Trading in History and Theory, 24 Law \& Contemp. ProB. 243-47 (x959); of. Pisar, Treatment of Communist Foreign Trade Arbitration in Western Courts, in International Trade Arbitration: A Road to World-Wide Cooperation Ioi, ro6 (M. Domke ed. I958).
} 
mercial arbitration represents a far more formalistic channel for dispute-settling than international trade arbitration in the free world.

Early Soviet trade agreements with the new socialist states, concluded at a time when the process of sovietization of their governmental and social institutions was not yet accomplished, followed the pattern of trade agreements with the capitalist countries. Arbitration of trade disputes was assigned a role comparable to that accorded in' free economies. But in due course, when the new countries uniformly introduced the principle of economic planning into foreign trade relations, new meaning was given to treaty provisions concerning settlement of disputes with socialist trading partners. In their modified role, trade agreements became channels for the coordination of the economic plans of the socialist countries. ${ }^{3}$ As a consequence of this evolution, various private arbitration reservations applicable to trade relations with the capitalist countries were no longer necessary, since arbitral tribunals in socialist states acted within identical social and economic settings. ${ }^{4}$

The history of dispute settlement in the socialist commonwealth of nations shows that commercial arbitration has a strictly limited significance, despite its connection with economic activity, which is of central importance in the communist world outlook. Commercial arbitration is not looked upon as a source of ideas and practices valid for the techniques of wider international relations among the socialist states. It has an important role in the context of international trade and is marginal to the basic function of economic management. The need for arbitration in international commercial relations resulted from the same situation that had called for arbitral services in the national context: governmental agencies responsible for a service or for industrial activity, cooperating under the terms of the economic plan, lacked an immediate superior able to resolve their conflicts of interest.

\section{I}

Arbitral Clauses in International Agreenemis

\section{A. Multilateral Treaties}

Multilateral agreements among socialist countries containing provisions on commercial arbitration belong to the later period of the formation of the socialist commonwealth of nations. There are three such agreements. However, only one of them provides for the creation of a special tribunal with jurisdiction in a specially defined category of disputes. None of these treaties covers the entire commonwealth. Their operation is restricted to the Soviet Union and Eastern Europe, bound by close economic interests.

\footnotetext{
3 "A typical provision, which is to be found in all trade agreements between socialist countries, is that parties accept the obligation to 'conclude agreements,' including long term agreements, which mutually determine goods deliveries and other conditions, assuring the expansion of trade in accordance with the needs of the national economy." Usenko, Torgovye dogovory mezhdu sotsialisticheskimi stranami, I96r VNeshinata ToRgoveia No. 5, at 5.

- Usenko, supra note 3, at 9. Cf. Domke, Arbitration of State-Trading Relations, 24 Law \& ConteMrp. Proв. 318-rg (I950); Pisar, suspra note 2, at rog.
} 
Chronologically, the first of these treaties was the agreement concluded by the shipping administrations of the Danubian states, signed in Bratislava on April 26, 1955, on towing, assistance to ships and persons in distress, and harbor administration and agency. Article 70 of this agreement provides that:

Shipping administrations participating in the present agreement shall adopt proper
measures for the peaceful settlement of all disputes which may arise in the execution
of the present agreement or in connection with all related matters. Disputes which
are not peacefully settled shall be subject to arbitration in the country of the de-
fendant-jurisdiction of the general courts being excluded. The parties may also
agree that an arbitral tribunal of another country shall be competent to adjudicate
their disputes.5

The term "peaceful settlement" is obviously used not to contrast the situation covered by this term with the use of force or threat of force, but with formal litigation. The treaty refers to the general experience that trade operations give rise to differences of opinion, which are settled normally by negotiation and mutual concessions, and that resort to litigation is an exceptional method of resolving such differences.

As of January $\mathrm{I}, \mathrm{r} 95^{8}$, an international code of commerce came into force between the members of CEMA under the name "General Conditions of Delivery." Its article $6_{5}$ states as follows: "All disputes shall be subject to arbitration, the jurisdiction of general courts being excluded, in an arbitral tribunal established for such disputes in the country of the defendant or, by agreement of the parties, in a third member country of the Council for Mutual Economic Assistance."

General Conditions of Delivery apply only to trade relations among the members of CEMA; that is, the U.S.S.R., Albania, Bulgaria, Czechoslovakia, Hungary, Rumania, and Poland. In the summer of 1962 Mongolia joined the Council for Mutual Economic Assistance and automatically became subject to the General Conditions of Delivery. There was, however, no official announcement to this effect.

The latest of the multilateral agreements which set up arbitral jurisdiction for disputes arising out of international commerce is the International Arbitration Court for Maritime and Cabotage Shipping in Gdynia established by the chambers for international commerce of Czechoslovakia, East Germany, and Poland in an instrument signed on July 17 , 1959 . The tribunal was created to deal with disputes concerning the activities of the shipping organizations of the three countries, with the exception of litigations arising from labor relations, which come under the domestic courts of the contracting parties.

The Gdynia Tribunal is the outcome of close cooperation of the three countries in the field of international shipping and maritime commerce. Czechoslovakia, a landlocked country, has its home ports in Polish and East German harbors. This

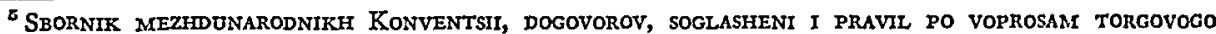
aoveplavaniba (Collection of International Conventions, Treaties, Agreements and Regulations oN MARTTIMe TRADE) 406 (I959) [hereinafter cited as STM-USSR].
} 
permits Czechoslovakia to maintain a merchant marine and to ply trade under its own flag. In addition, the three countries handle a sizable amount of goods delivered at Baltic ports in transit to other European countries of the communist bloc. Furthermore, Polish and East German shipyards serve international shipping in the Baltic area.

The Gdynia Tribunal is an elaborate structure. Its organization and operation were carefully provided for in a series of agreements which included:

(I) an agreement on the creation and maintenance of the International Arbitration Court in Gdynia,

(2) rules of procedure,

(3) an agreement on costs of proceedings,

(4) an ordinance on the honorariums and fees of the members of the Arbitration Tribunal, and

(5) an additional protocol regulating various incidental problems. ${ }^{6}$

\section{B. Bilateral Agreements}

The main body of legal rules providing for the jurisdiction of commercial arbitration tribunals is to be found in the bilateral agreements concerning international commerce among the socialist nations. These deal with various aspects of economic cooperation, foreign' trade, shipping, fishing, and safety at sea.

Provisions of these treaties are governed by two basic principles. In the first place, they establish general conditions for the conduct of trade and maintenance of commercial relations among the socialist countries. Secondly, they give effect to the principle that foreign trade and commerce comprise a governmental monopoly established to marshal goods and commodities for export and import according to the national economic plan. Such a plan provides for the quantities of domestic goods to be exported and foreign goods to be imported, and determines the volume of services to be rendered in shipping, banking, transit through ports, harbors, and railway lines, loading, unloading, and haulage. In short, all activities which constitute an integral part of the international circulation of goods and services are covered by the plan.

Foreign trade relations represent the fulfillment of international obligations in a dual sense. In the first place, exports and imports meet the terms of contracts and of the yearly trade agreements concluded between interested countries. In recent years, however, trade operations have represented fulfillment of a broader obligation incumbent upon the members of the Council for Mutual Economic Assistance. They have to meet the trade targets set up not only in terms of bilateral agreements, but in terms of a general program of economic integration under the auspices of CEMA, including specialization of individual countries according to the plans for the division

\footnotetext{
${ }^{\circ}$ Domke, Schiedsgerichts und Kostenordnung des 1959 errichteten internationalen Schiedsgerichts fuer Sce und Binnenschiffahrt in Gdynia, 6 Osr Eunopa-Recht 74-82 (I960). Spitzner, Osmar \& Fellhauer, Die internationale Schiedsgerichts fuer See und Binnenschiffahrt in Gdynia, 9 AussenHANDEL No. 13, at 3I-33 (1959).
} 
of labor. ${ }^{7}$ Consequently arbitration of disputes is primarily looked upon in terms of the overall objectives of maintaining the flow of deliveries, of removing bottlenecks, and of assuming performance of mutual obligations.

Bilateral treaties and agreements containing provisions on arbitration fall into two categories. To the first category belong all those agreements which establish a legal framework for business transactions involving imports and exports of goods and their transit in intrabloc trade, usually styled trade and navigation conventions. By $196 \mathrm{r}$, there were seventeen such bilateral agreements in force between members of the socialist commonwealth of nations, the majority of them containing provisions concerning arbitration.

With the exception of treaties concluded by Poland, East Germany, and Czechoslovakia, all treaties contain provisions stipulating that the parties shall give effect to arbitral decisions in litigations arising from transactions between their business organizations. None of the treaties, however, provides for an obligation to submit such disputes to arbitration. ${ }^{8}$

Execution of arbitral awards is made dependent upon the condition that contracts between commercial institutions of the countries concerned contain a provision that disputes over the contract shall be submitted to arbitration, either in a general manner, or specifically by a determined international tribunal. Such a condition may also be set in an additional agreement, in which case the form prescribed for the business transaction must be observed. ${ }^{9}$

The second category of agreements containing provisions on arbitration concerns the establishment of a common regime for all participating nations in certain broad areas of international trade and commerce. Three such treaties were concluded in the course of 1956 , dealing with the rescue of persons and of ships or aircraft in distress on the high seas. The first is a U.S.S.R. treaty with Poland and East Germany dated July 7 , 1956 , covering the Baltic; ${ }^{10}$ a similar Soviet treaty with Red

\footnotetext{
${ }^{7}$ Reporting to the Twentieth Congress of the CPSU (1956), Khrushchev stated as follows:

Equal and mutually profitable trade relations, exchange of technical information, mutual assistance, and effective coordination of national economic plans have been established between the socialist countries. Close economic cooperation opens up singular possibilities for the most advantageous exploitation of raw materials and industrial equipment, and effectively brings into harmony the interests of each country with the interests of the socialist camp as a whole. There is no urgent need at present for each socialist country to develop all branches of heavy industry.

Izvestia, Feb. $15, \times 956$.

${ }^{8}$ Usenko, supra note 3 , at 2-Ir.

- Article 14 of the U.S.S.R. Navigation Treaty with Rumania of February 20, 1947, STM-USSR 26778; article I7 of the U.S.S.R. Treaty with Hungary of July 15, I947, id. at 278-82; article 14 of the U.S.S.R. Treaty with Czechoslovakia of December I, 1947, id. at 282-85; article 18 of the U.S.S.R. Treaty with Bulgaria of April $\mathrm{r}$, 1948, id. at 286-88; article 16 of the U.S.S.R. Treaty with Albania of February 15, 1957, id. at 314-16; article 16 of the U.S.S.R. Treaty with North Victnam, id. at 316-18; and article $I 6$ of the U.S.S.R. Treaty with the Chinese People's Republic, id. at 814-15.

The General Conditions of Delivery of 1958 established a duty for CEMA members to submit their trade disputes to arbitration. It would seem, therefore, that provisions of the bilateral treaties concerning arbitration were replaced by the General Conditions. However, bilateral trade agrecments concluded after I958 describe various formal aspects of contract-making that must be adhered to in order to establish the duty to arbitrate.

${ }^{10}$ STM-USSR $185-87$.
} 
China and North Korea (July 8, 1956) encompasses the high seas adjacent to the coastal areas of those three countries; ${ }^{11}$ and a treaty for the Black Sea was adopted by the Soviet Union, Bulgaria, and Rumania. ${ }^{12}$

Procedures established by the three agreements follow a single pattern for all three areas. Rescue operations are undertaken on the basis of the so-called rescue contract, concluded, if possible, before rescue operations have begun. As a matter of course, rescue contracts should provide for the jurisdiction of a court or of an arbitral body to decide disputes arising from the contract of rescue. ${ }^{13}$

II

\section{Operation of the Soctaitst System of Commerctal Arbitration}

\section{A. Organization}

Commercial arbitration in the socialist commonwealth reflects two principles in its institutional and procedural arrangements. Foreign trade within the legal and economic order of each socialist nation is a government monopoly and an administrative activity. Foreign trade is also a world business, which must be treated in terms of broader interests. Soviet institutions for commercial arbitration came into being at a time when Soviet foreign trade was conducted exclusively with the capitalist countries and had to comply with the general usages and practices followed in international commerce, taking into account the fact that Soviet partners in trade at that time were invariably private persons or business organizations. These basic facts influenced the organization of the foreign trade mechanism of the Soviet Union and later that of the new socialist states. They have also shaped the techniques of commercial arbitration set up by the Soviet Union and other members of the commonwealth to settle disputes arising in this connection.

In practical terms, the socialist countries have adopted a general policy of bringing foreign trade agencies as close as possible to the patterns prevailing in the world at large. Trade is handled by organizations resembling private commercial bodies engaged in international commerce. Each socialist country has organized its own international chamber of commerce, which is the official sponsor of commercial arbitration. Chambers of commerce, first established in the Soviet Union and later initiated in all socialist countries, are associations of representatives of the trading interests in each country, bearing no direct connection to the ministry of foreign trade, which is in charge of the government monopoly of foreign trade.

In imitation of their counterparts in capitalist countries, socialist chambers of commerce supervise the progress of foreign trade relations, study trade and economic conditions abroad, promote trade and foster economic cooperation, assist in organization of fairs and exhibitions, arrange exchanges of experts, and study trade tech-

\footnotetext{
${ }^{11}$ Id. at $177-79$.

${ }^{12}$ Id. at I79-81.

${ }^{23}$ Article 6 of the Baltic Treaty, article 8 of the Black Sea Treaty, and article 9 of the Far Eastern Treaty.
} 
niques. In addition', they issue proper attestations as regards the quantity and quality of goods, and issue affidavits pertaining to trade usages and commercial practices. Chambers of commerce are separate entities and their transactions are not official acts of government.

At the same time, because foreign trade is a government monopoly, chambers of commerce are bound by the instructions of the foreign trade ministers. They were established by governmental decrees, as associations of government corporations, institutions, and agencies engaged in foreign trade. As the activities of the chambers of commerce are within the scope of governmental operations, they are also governed by the general rules of public administration. The statutes of the chambers of commerce provide for two categories of membership: (I) regular members-governmental institutions and state corporations engaged in export or import of goods, and cooperatives and banks active in foreign trade; and (2) corresponding members -experts in the field of foreign trade. ${ }^{14}$

The main function of the chambers of commerce in the socialist countries is to provide an organizational framework for commercial arbitration. In spite of the uniformity of their organization and functions, the terminology used to describe socialist chambers of commerce varies considerably. In some countries they are called chambers of commerce, or chambers for international or foreign trade. The legislation describes similar institutions in Communist China and North Korea as governmental committees for the promotion of international trade, offering little disguise as to the administrative nature of their functions. ${ }^{\mathbf{1 5}}$

Commercial arbitration tribunals established in socialist countries fall into two categories. Countries with considerable interest in shipping and maritime trade have established separate arbitration bodies to handle disputes in that area. The U.S.S.R. and China have each set up a national arbitration tribunal for that purpose. Poland, East Germany, and Czechoslovakia have jointly established an international tribunal for maritime commerce in Gdynia to handle cases involving one or more of the parties involved. In the above five countries foreign trade arbitration tribunals do not handle disputes arising from shipping and maritime trade, but concern themselves exclusively with foreign trade transactions. ${ }^{18}$

The Soviet statute on the Maritime Arbitration Commission of the All-Union

\footnotetext{
14 See Berman, supre note 2, at 492 f.; Pisar, The Communist System of Adjudication, 72 Hanv. L. REv. I409, 1426-27 (I959); Sipkov, Foreign Trade, Chamber of Commerce and Foreign Trade Arbitration Commission Under Communist Government, 4 Highligrts 423-34 (1956); cf. Polish Decree on the Organization of the Polish Chamber for Foreign Trade of September 28, 1949, I949 Dziennik Ustaw (Polish Offictax. Law GazetTe) No. 53, and the announcement of the Czechoslovak Minister for Foreign Trade and of the Minister of the Interior, concerning the organization of the Czechoslovak Chamber of Commerce, r952 SBirka zaxonv (Official Gazetre of Czechoflovakia) No. 205. See also K. Fellfauer, Der Aussenhandelskaufman und die Schiedsgerichte i8-ig (I959); P. Statnov \& A. Angelov, Administrativno pravo na narodnata republika Bulgarua, -spetsialina Chast 192 (1954); Koch, Die Kammer in Dienste der Aussenhandelforderung, 1959 Der Aus-senHANDEL No. $\mathrm{r}$, at 31-32; Ramzaitsev, Pravovoe polozhenie vneshnetorgovoi arbitrazhnoi Kommissii, I955 Soverskoe Gosodarstvo I Pravo No. 3 , at 80 .

${ }_{15}$ Fellahuer, supra note 14 , at 137,146 .

${ }^{10}$ Id. at r90-99; Domke, supra note 6, at 74-82; Spitzner, Osmar \& Fellhauer, supra note 6, at 31-33.
} 
Chamber of Commerce, approved on December 15, 1930, set the pattern for the operation of the international trade arbitration system in the socialist commonwealth. ${ }^{17}$ It was followed by the Foreign Trade Arbitration Board, established by the Act of June I7, I932, also attached to the All-Union Chamber of Commerce. ${ }^{18}$

The first among the people's democracies to establish a similar institution was Yugoslavia (r946). Yugoslav organization of government arbitration, including the foreign trade arbitration commission, underwent numerous changes and in 1954 was replaced by a system of economic courts. The rules of procedure for the Court of Arbitration for Foreign Trade were revised in $1958 .{ }^{19}$ In Poland a College of Arbiters for foreign trade was established in $1949 .{ }^{20}$ Commercial arbitration tribunals were established in Czechoslovakia ${ }^{21}$ and Bulgaria ${ }^{22}$ in $195^{2}$, in Hungary $^{23}$ and Rumania $^{24}$ in 1953 , in East Germany ${ }^{25}$ and Communist China ${ }^{26}$ in 1954 , in North Korea $^{27}$ in 1955 and in Albania ${ }^{28}$ in 1959.

The first tribunals only remotely resembled their Soviet models, which were examples of simplicity that offered little choice as to the persons of arbiters and little flexibility regarding rules of procedure. In contrast with the Soviet models, the rules of procedure originally adopted for the commercial arbitration tribunals in Poland, Czechoslovakia, and Hungary followed the Western pattern. They featured loose organization, wide opportunity for choice of arbiters, and studious informality in proceedings. Panels of arbiters were large. Members were selected because of their expertise and their connections with various aspects of economic activity. This type of organization however, while quite appropriate for commercial arbitration as understood in the West, was quite inadequate for the needs of socialist trade.

Large panels of arbiters were unable to maintain contact, exchange experience, and develop a consistent line of practice for specific types of cases. Rarely called upon to participate in adjudication of cases, members of the commercial arbitration tribunals were inclined to treat each case as a separate event, considering issues of fact

\footnotetext{
${ }^{17}$ V. Gsovski, I Soviet Crvin Law 874-75 (1948); Statute of the Maritime Arbitration Commission attached to the U.S.S.R. Chamber of Commerce, Sovier Laws I930, No. 637; Sovier Laws I933, No. 12; SOviET LAws I936, No. 22.

${ }^{18}$ SOVIET Laws 1932, No. $28 \mathrm{r}$.

10 1958 Sluzbeni list Denokratske Federativine Judoslavje (Yugoslav Official Gazette) Nos. I, 28. See V. Gsovski \& K. Grzybowski, I Government, Law, and Courts in the Soviet Union and EASTERN EUROPE 820-21 (1959).

${ }^{20} 1949$ Dziennik Ustaw No. 53; cf. Gibas, Nowy Regulamin Kolegium Arbitrow przy Polskiej Izbie Handlu Zagranicznego, 1959 HaNdel ZaGRANICZNY No. 5/6, at 238.

${ }^{21}$ Fell hauer, stupra note 14 , at 87 .

22 Announcement of Feb. 4, I952, I952 Izvestia Na Presidiuma Na Narodnoto Subranie (Bulgarian Official Law Gazette) No. iog; Fellhauer, supra note i4, at 95.

${ }^{23}$ The Hungarian Court of Arbitration was established on August 28, 1953, I953 MAgyar KozLoNy (Hungaran Official Law GazetTe), Aug. 28. Its organization was changed by the regulation of the Minister of Foreign Trade, 959 Magyar Kozlony, Jan. I4; Fellhauer, supra note 14, at i19.

${ }^{2} 1953$ Boletinul Oficial (Rumanian Official Law Gazette) No. 29; Felliauer, supta note 14, at 119 .

at Fellhauer, supra note 14 , at 127 .

${ }^{20} \mathrm{Id}$. at $\mathrm{I} 37$.

${ }^{27} I d$, at 146 .

${ }^{29}$ I956 Gazeta ZyratARe (Almanian Offictar. Law Gazette) No. 2864.
} 
and commercial practice in terms of equity and fairness. As foreign trade between socialist countries expanded, and the integration of the national economies gained momentum, these rather loosely organized panels of arbiters were no longer satisfactory and were replaced by smaller and more cohesive organizations..$^{20}$

The ties between the chambers of commerce and the panels of arbiters from which arbitration tribunals are selected to adjudicate in individual cases are rather intimate. Usually it is the business of the chambers of commerce to enact rules of procedure for commercial arbitration. They select the members of panels of arbiters who serve for a period ranging up to two years. Either the chairman of the chamber of commerce or the plenary meeting of the chamber elects the so-called presidium of the tribunal and a secretary to handle its business during the preliminary proceedings and to administer its affairs. In certain tribunals, this role is fulfilled by a single officer (secretary general) who administers the business of the arbitration tribunal.

The number of members on the panel of arbiters varies, but in the majority of cases is rather limited. The Albanian panel has only seven members and the North Korean Arbitration Committee numbers from eleven to fifteen arbiters. The Soviet Maritime Arbitration Board and the arbitral tribunals of Bulgaria and Rumania number fifteen members each. The Chinese Committee has a minimum of fifteen and a maximum of twenty-one members, while the Soviet Foreign Trade Arbitration Board has twenty-one arbiters. The Chinese Maritime Arbitration Board again adopted the minimum-maximum system of twenty-one to thirty-one members. The arbitral tribunals of Poland, Czechoslovakia, East Germany, Hungary, and Yugoslavia have established no set numbers for their panels of arbiters.

The Gdynia Maritime Arbitration Tribunal reflects in its organization the fact that it is a body set up by three nation's. Each contracting party (East Germany, Poland, and Czechoslovakia) appoints a member of the presidium and his deputy. The presidium consists of three members, with the office of the president going to a different country each year; the secretary is appointed by the members. In addition, each of the participating chambers of commerce appoints ten members to the panel of arbiters. This presidium represents an important and a permanent part of the arbitral organization.

According to the Polish rules of I959 (section Io), the presidium consists of its chairman, three deputies, the secretary, and his deputy, who are appointed to and dismissed from office by the Council of the Chamber for Foreign Trade. The duties of the presidium include: filling the position of the secretary and his deputy in case of vacancy; selecting panelists for the list of arbiters; making a decision if an arbiter is challenged by one of the parties; making decisions concerning jurisdiction; giving legal opinions on questions addressed by the arbitral tribunal considering a case; setting the place and time of hearings; and deciding the case on the merits in the event the claim was acknowledged by the responding party before the arbitral tribunal was set up.

\footnotetext{
${ }^{20}$ Gibas, supra note 20 , at 237 .
} 
The size of the presidium varies from two members (the chairman and his deputy) in Albania, to eleven members (a chairman, six regular members of the presidium, three alternate members, and a secretary, who is the head of the secretariat) in Czechoslovakia. As a matter of course, members of the presidium, including the chairman and his deputies, must have the same qualifications as other members of the arbitral panel. They are either elected by the current panel, ${ }^{30}$ or appointed by the chamber of commerce. ${ }^{31}$

Bulgarian and Hungarian arbitration tribunals differ from these two patterns. The Bulgarian panel elects its secretary, who is in charge of the administrative aspects of the arbitral proceedings, while the functions of the presidium which are not of a judicial nature are exercised by the presidium of the chamber of commerce. Its main function is to organize the judicial team which undertakes the examination of the case on the merits. In Hungary, the panel of arbiters has no corporate function of its own, and until a judicial team is established to sit in on a case, all administration connected with commercial arbitration is in the hands of the administrative personnel of the chamber. Administrative functions in connection with individual cases, such as transmission of pieces of procedure, service of documents, and other clerical business, are the responsibility of a special secretary for legal affairs, appointed by the secretary general of the chamber, who performs some of the duties that in other tribunals fall to the presidium.

Nationality of the arbitrators represents one of the key factors determining the role and function of commercial arbitration in socialist countries. Under the traditional system, parties have a free choice of persons to serve as arbitrators, and nationality does not restrict their participation in commercial arbitration. At this point private arbitration has differed from court proceedings and judicial decision. The current trend in the socialist commonwealth to establish commercial arbitration as an instrument for promoting foreign trade, and to assure uniformity of arbitral decisions, is reflected in the tendency to restrict the number of panelists and to exclude foreign nationals from arbitration tribunals.

Not all rules and statutes of the commercial arbitration tribunals are clear on this point. Soviet rules for both commissions are silent on the nationality of arbiters. In the beginning, foreign nationals participated as arbiters in a number of cases brought before the Soviet Maritime Arbitration Commission or before the Foreign Trade Arbitration Board. As a rule, however, such foreign citizens were employed by the Soviet state. ${ }^{32}$

With the exception of the Hungarian and Czech rules, statutes of other socialist countries follow the Soviet pattern. Any competent person may be placed on the list

\footnotetext{
${ }^{30}$ U.S.S.R. Foreign Arbitration Board, U.S.S.R. Maritime Arbitration Commission, Chinese Arbitration Committee for Foreign Trade, Chinese Maritime Arbitration Commission, North Korean Arbitration Tribunal for Foreign Trade.

${ }^{31}$ East German Foreign Trade Arbitration Tribunal, Czechoslovak Commercial Arbitration Tribunal, Polish International Trade Arbitration Tribunal, Rumanian Tribunal for Foreign Trade Arbitration, Albanian Commission for Foreign Trade Arbitration, Yugoslav Court for Foreign Trade Arbitration.

${ }^{32}$ Goighbargh, 1935 Sovetskoe khoziaIstvo I vNEShNala torgovila No. 2, 20-31.
} 
of arbitrators, provided he is professionally qualified, and there is no requirement that only nationals may be admitted to the arbitral function. At the same time rules and statutes, except in Hungary, require that the arbiter be a member of the panel.

Before their revision in' 1957-59, Polish, East German, and Hungarian rules provided that only nationals could be arbiters on their tribunals. The revision has removed that restriction and, as a Polish jurist explained, this was done in order to permit appointment of foreign experts to the Polish panel. His comment would suggest, however, that the purpose of the reform was to assure admission' of experts from other socialist countries to the list of Polish arbiters and in this manner to contribute to the uniformity of arbitral practice throughout the socialist commonwealth. ${ }^{33}$

Czechoslovak and Hungarian rules have given formal expression to this new tendency. The Czechoslovak rule (section II) states expressly that foreign' citizenship does not prevent a person from being a member of the Czech commercial arbitration panel, while the Hungarian rule (section 4) goes even further, giving a foreign party the right to nominate an' arbiter who is a foreign national, even if he is not listed on the Hungarian panel of arbiters.

\section{B. Jurisdiction}

Rules on jurisdiction rely on two criteria to determine the scope of commercial arbitration: subject matter of disputes, and class of persons admitted to be parties in disputes. Definitions of disputes by subject matter use a terminology which is clearly not exhaustive. Rules of commercial arbitration contain only a general indication of the nature of litigation that the tribunals have the power to entertain.

The Soviet statute on the Foreign Trade Arbitration Commission states that the Commission was established "for arbitration of disputes arising from legal transactions involving foreign trade." The statute on the Maritime Arbitration Commission is more specific and lists the following classes of disputes as within its jurisdiction: (I) disputes over compensation for assistance rendered by seagoing vessels to each other, or by seagoing vessels to a rivercraft or vice versa (salvage); (2) disputes arising out of collision of seagoing vessels and rivercraft, or disputes arising from damage caused by seagoing vessels to port structures; and, finally (3) disputes growing out of relations of affreightment of seagoing vessels, steamship agency services, and maritime shipping (by consignment), as well as disputes arising from marine insurance.

The list of legal transactions and of factual situations which may occasion claims from the parties involved is even more specific in the provisions of the rules of the Gdynia Tribunal of Arbitration, while the rules of the Chinese Maritime Arbitration Tribunal are closer to the Soviet model.

On the whole, provisions determining jurisdiction of the commercial arbitration tribunals are less elaborate. Polish rules speak of trade transactions, transport, and

\footnotetext{
${ }^{33}$ Gibas, supra note 20 , at 237.
} 
insurance contracts. German rules add banking transactions to this list. Some rules refer generally to legal disputes and claims arising from foreign trade transactions or to financial and property claims that arise from these transactions, and so forth. It is clear that, whatever the formula, the key is not in the listing of various classes of commercial transactions which may lead to conflict between parties, but in their connection with foreign trade operations.

Somewhat more precise are the terms used to specify those who have the right to appear and sue before the commercial arbitration tribunals or to be admitted there as respondents in proceedings before them. This right belongs to domestic economic organizations and to foreign firms, legal entities, and persons residing abroad.

Not all rules are specific in determining persons who may sue or be sued in commerical arbitration proceedings. Polish rules, for instance, are primarily concerned with the subject matter of the disputes, inasmuch as they restrict commercial arbitration to true foreign trade transactions; "The scope of activity which is assigned to the college of arbiters is to determine disputes resulting from bilateral commercial transactions, or from transport or insurance of goods, if one of the parties is a physical or a juristic person permanently residing outside the borders of the Polish People's Republic," (section I2).

The key in this formula is in the term "bilateral commercial transactions" with the participation of a foreign trader. The Polish party must be an appropriate economic agency, ranging from the Ministry of Foreign Trade to a union of agricultural cooperatives exporting farm products to foreign countries. The requirement is that their activity fall within the scope of foreign trade. As regards the foreign trader, he must also be a merchant according to the law of his country. In the final analysis, the rules of arbitration tribunals take account of legal complexities arising from the fact that they are designed to cover trade operations between socialist and capitalist countries.

Matters are far simpler in disputes resulting from trade operations with other socialist countries. The issue of jurisdiction in terms of the legal capacity of the claimant or respondent is always determined by his national law. The broad terminology employed in the relevant socialist law leaves little opportunity for challenging the right of the foreign person or entity to appear before the commercial tribunal of a socialist state. Furthermore, it must be realized that the other party to the commercial transaction is invariably the recognized state trader competent to handle foreign trade operations within his specific field of responsibility.

The issue of jurisdiction, therefore, would arise almost exclusively in connection with the legal basis for arbitration. ${ }^{34}$ Jurisdiction is based on the agreement of parties

\footnotetext{
${ }^{34}$ Jurisdiction constitutes the central question of the preliminary proceedings leading to the establishment of the arbitration tribunal and consideration of the dispute on merits. The presidium or the secretary of the arbitration tribunal endeavors to complete the dossier of the case as to the point of jurisdiction by obtaining proper documents and statements from the parties. Section I(3) of the Hungarian Rules provides that the arbitration tribunal examines its jurisdiction ex officio. Sce also article 12 of the Yugoslav Rules.
} 
to submit their disputes to arbitration. It may take the form of a general arbitration clause in an international treaty. This is the source of the obligatory jurisdiction of commercial arbitration tribunals over cases falling within the field of foreign trade transactions. It may also take the form of a specific arbitration clause, included either in the contract covering the original transaction out of which the dispute originated or in a subsequent agreement, even in the course of the proceedings. ${ }^{35}$

General arbitration clauses are found in two international agreements. Under the terms of the General Conditions of Delivery of $x 95^{8}$ (article 65) members of the Council for Mutual Economic Assistance have agreed to submit their disputes regarding the application and interpretation of provisions of the General Conditions to arbitration. An identical provision was included in the agreement between the shipping organizations of the Danubian states of April 26, I955, concerning towing, assistance to ships and persons in distress, and administration of the Danubian ports and agency.

While the provisions of the agreement concluded by the Danubian shipping organizations have a limited application, article 65 of the General Conditions of Delivery also applies to all commercial transactions in maritime trade, inasmuch as they deal with sale and purchase of goods, their delivery, and all technical aspects involved in commercial operations of this type.

Procedural rules of the various tribunals differ considerably as to the manner by which the agreement of the parties to submit disputes to arbitration is established. The Soviet, Hungarian, Rumanian, Chinese, North Korean, and Albanian rules of procedure have no provisions regarding the submission of a dispute to arbitration in the course of proceedings. The matter of jurisdiction must be resolved in the affirmative before the claim is communicated to the respondent. The question of jurisdiction at that stage is determined by the administrative elements of the tribunal of arbitration. The chairman, the presidium, or the secretary of the tribunal must take proper steps to clarify all preliminary questions including whether the parties have agreed to submit their dispute to arbitration, or whether there is some other basis (international agreement) for arbitral action.

The other group of arbitral procedures differs in that it offers an additional opportunity in the course of proceedings to accept the jurisdiction of a commercial arbitration tribunal to decide the case. According to the Polish rules, both parties may accept the tribunal's jurisdiction in the initial phase of proceedings, before the case is considered on the merits. The claimant in his claim and the respondent in his rejoinder may in writing submit their dispute to arbitral decision. Under Czechoslovak rules, the secretary of the court may also elicit from the parties by means of requests for additional information an agreement to have their dispute arbitrated. Under the third system (in Bulgaria and East Germany), the agreement to arbitrate is reached by facta concludentia, when the respondent raises no preliminary objection

\footnotetext{
${ }^{35}$ See section 2 of the procedural rules of the Gdynia Tribunal.
} 
as to the tribunal's jurisdiction but, in answering the initial procedural piece, goes into the merits of the case.

One may surmise that these differences result from different legal traditions. Countries strongly influenced by the French civil code rely upon the written form in contracts for arbitral agreements and indicate a general preference for documentary evidence (a peculiar characteristic of Soviet private law also). Their laws will, in this respect, differ from those influenced by the Austrian, German, or Swiss civil codes. But in practice these differences are of minor significance. Uncertainties over jurisdiction are unlikely to arise in foreign trade relations among the socialist countries. Trade is a bureaucratic process; while efficiency in terms of actual performance may suffer, resort to standardized forms and attention to procedures and intergovernmental agreements relating to the form and conditions of economic cooperation will almost certainly avert situations where the issue of jurisdiction remains in doubt.

\section{Procedure}

Arbitral proceedings fall into two distinct phases. During the first phase preliminary issues are settled and points of controversy are clarified. The dossier of the case is prepared by procuring all necessary documents pertaining to the jurisdiction of the tribunal and the final phase of litigation, that is, a hearing on the merits.

The statutes of arbitration tribunals and the rules of procedure of all socialist countries tend to emphasize the institutional character of commercial arbitration. With the exception of Hungary, whose rules omit the institution of the presidium, a case submitted by one of the parties is handled by a body of elected or appointed officers, called to represent the entire establishment of arbiters. The permanent officers of the court, the chairman of the presidium, or the secretary receive and transmit the opening pieces of procedure, rejoinders, documents, and statements of the parties regarding jurisdiction, invite parties to appoint members of the tribunals, and ask arbitrators to select their umpire.

If there is no agreement either between the parties or the elected arbiters as to who the umpire shall be, the presidium, the chairman of the presidium, or, in the case of the Hungarian arbitral tribunal, the chairman of the chamber of commerce selects the umpire. If the parties have chosen to have the case decided by the body selected by the presidium, it appoints a single arbitrator.

In addition, the presidium endeavors to expedite proceedings in order to bring the case to trial on the merits. It designates the deadline for the production of documents, the submission of proper pieces of procedure, and the supplying of translations. It hears and decides challenges by the parties of individual arbitrators, and it examines the legal grounds for refusal of appointed arbiters to assume their duties. The rules of some of the commercial arbitration tribunals give the presidium the power to decide the case finally. According to Polish rules, the tribunal will rule according to the demands of the claim if it was acknowledged fully by the respondent 
in his rejoinder. The presidium may also declare the tribunal incompetent if it lacks jurisdiction.

The statement of the claim is a highly technical piece of procedure. The statement concerning jurisdiction should be substantiated, the claim must be defined, and evidence and proof offered in support of the claim must be listed. The responding party may challenge the claim either on formal or substantive grounds. It may also file a counterclaim, which will be subject to the decision in the case unless it is already a subject of separate proceedings before another judicial or arbitral body.

The preliminary stage of the proceedings comes to an end when the arbitral team is established to decide the case on the merits and when the case is transmitted to its presiding judge. At that moment the presidium terminates its actions in the case, unless called later to render stipulated assistance.

The arbitral tribunal called upon to decide a case on the merits usually consists of three members, two selected by the parties and one selected by arbiters. Parties may agree to have their case decided by a single arbiter or may authorize the presidium or the chamber of commerce to set a tribunal to decide the case for them. In the latter case, a single arbiter will be selected. Some procedural rules leave the size of the tribunal to the decision of the parties, who may agree that more than three arbiters will take part in the proceedings. In an effort to assure the successful completion of proceedings, some of the rules of procedure provide for the appointment of alternate arbiters and a deputy chairman to sit in on a case and to substitute for the chairman or a member of the tribunal, where one of the latter is unable to fulfill his duties.

As a rule, proceedings are conducted in the language of the country where they are held. However, in practice, arbitral tribunals can conduct proceedings in any international language and receive pieces of procedure in foreign languages. Sometimes the rules restrict the choice of languages to those used by the parties in their commercial correspondence. The party using a foreign language is usually called upon to bear the cost of translations. Rules of procedure in all the socialist countries provide for interpreter services to assist a party unfamiliar with the language of the tribunal. The Polish rules of 1959 (section 25) provide that the tribunal may decide, with the agreement of the parties, to conduct hearings in English, French, German, or Russian, if this would speed up the proceedings.

Hearings are oral and public, unless the parties agree to have their case heard in camera or unless the tribunal decides to do so for reasons of public interest. Parties may be represented by lawyers, and a foreign party may bring his own lawyer who may plead the case in the language of his country, provided that proper interpreter's services are provided. Witnesses are heard and examined in their own language, and parties may also make statements in their own tongue.

Evidence is ruled by the principle of relevance. Beyond that principle, there is no restriction as to the admissibility of evidence in arbitral proceedings. The method of presentation and evaluation is left to the discretion of the tribunal. It is the re- 
sponsibility of parties to submit evidence in substantiation of their pleadings. However, the tribunal may seek additional evidence on its own initiative from experts invited to submit opinions on technical questions of fact and interpretation of foreign customs or usage. The tribunal may delegate one of its members to hear evidence which cannot be presented to the entire tribunal at the site of the hearings.

Full records of proceedings are kept and are signed by the presiding judge and the tribunal's secretary. In contrast with Anglo-Saxon practice, the presiding judge controls the proceedings and the production of evidence. He questions the witnesses and experts, but other members of the tribunal and the parties themselves are also given the opportunity to participate in the questioning. It is possible to appeal the rulings of the presiding judge to the entire tribunal. In general, proceedings before socialist arbitration tribunals are a fair imitation of the proceedings in European courts of justice.

Contrary to the general practice prevailing in commercial arbitration in the West, rules of procedure require that awards as well as dissenting opinions be reduced to writing and that a full statement of reasons therefor be included. They are comparable in form to the judicial decisions of regular courts in the West. They give the names of the parties and of the arbiters, the principal arguments submitted, an analysis of the legal principles involved, reference to facts as established by evidence, and other data regarding various rulings made by the tribunal. They must also contain directives as to the execution of awards.

It is the duty of an arbitral tribunal to offer the parties the possibility of settling their differences out of court or by composition in court. ${ }^{36}$ The Czechoslovak rules, as amended in 1957, as well as the rules of procedure of the Yugoslav Court of Foreign Trade Arbitration, provide for conciliation proceedings to be conducted with the agreement of the parties before a tribunal specially composed for that purpose. It consists of two members, delegated by the disputants under the chairmanship of the secretary of the court or of the appointed member from the list of arbiters. The purpose of the hearings is to clarify the issues, to formulate conciliation proposals, and to arrive at an agreed settlement. Statements made in court have no bearing upon future proceedings before an arbitration tribunal. Submission to conciliation proceedings does not depend upon the agreement of the parties to submit the issue to arbitration. The parties are under no obligation to accept the conciliation proposals or to submit their case to arbitration later.

III

Arbitration and the Unity of the Law of Socialist Foreign Trade

The success of private commercial arbitration in the world at large is due to several causes. In the first place, it is informal and expeditious and is conducted by knowledgeable men of affairs and experts versed in foreign trade and inter-

\footnotetext{
${ }^{80}$ D. Ramzaitsev, Morskor Arbitrazh v Sovetskom Solvzie I 8 ff. (I956); Domke, The Israeli-Soviet Oil Arbitration, 53 Am. J. INT'L L. 787 (1959); Pisar, supra note 14, at 4444 ff.
} 
national business transactions. In effect, this assures not only a correct solution of disputes but also a predictable solution.

At the same time, private arbitration has an additional advantage over the regular courts in that arbitral decisions are less dependent upon strict interpretation of the law in force or upon a custom or practice followed by business circles. In certain circumstances, perhaps exceptional, where the normal rules of risk would not result in substantive justice, a private commercial arbitrator can adjust the claims and rights of the parties not according to the strict rules of commerce, law, or practice, but in equity.

While commercial arbitration in the West would tend to strike a balance between formal and substantive justice, in the socialist countries it was designed with different aims in view. The nature of commercial adjudication in the socialist commonwealth is vitally influenced by the fact that it is in the hands of experts drawn from the ranks of the bureaucracy, who are charged with economic administration. To them, all operations are primarily assessed in the context of the economic plan. It is quite natural that in this milieu there should be a tendency to uphold regulations and instructions of higher authorities and to enforce the formal rule of law, rather than to seek a solution in terms of business practices. Furthermore, socialist commercial arbitration tends to establish firm rules of procedeure as guidelines for those members of the economic bureaucracy in charge of foreign trade operations.

Quite apart from those general considerations which would tend to develop uniform arbitral practices, statutes creating arbitration tribunals favor the growth of a comprehensive body of law concerning foreign trade transactions. In the first place, the limited number of arbitrators leads to their frequent participation in adjudication of cases, their interest in an important social and economic function, and frequent meetings and exchanges of opinion, even on informal occasions. Thus, members of the arbitral tribunals are made aware of the effect of adjudication on the general progress of trade activities among the socialist countries. Furthermore, the statutes of some arbitral tribunals provide for frequent general meetings of the tribunal to elect the chairman, his deputies, and the secretary. Some tribunals maintain a record of the decisions passed by the adjudicating teams of arbiters and arrange for their publication.

Under the rules of the Hungarian arbitral tribunal, the general meeting of arbiters is held at least once each quarter and is devoted to a discussion of legal problems designed to contribute to the development of the international law of foreign trade and assure uniformity of practice. The meeting hears the report of the secretary on the activity of the tribunal during the past quarter. There follows a discussion of basic questions concerning differences noticed in the practice of individual teams of arbiters or between individual members. General discussion may also deal with the desirability of changing the established practice and initiating a new method of deciding future cases. Finally, the general meeting considers all questions related to the activity of the tribunal, the law of commerce as it is being 
applied, or the law which is coming into force. After discussing various problems, the general meeting of arbiters passes a resolution which is binding upon its members in deciding future cases. Polish rules provide that the chairman of the college of arbiters may order publication of the arbitral decision if it contains a statement of an important legal principle or deals with a significant trade practice.

The tendency toward uniformity in commercial arbitration, as practiced by the tribunals of the socialist commonwealth, was considerably strengthened by the enactment of the General Conditions of Delivery of CEMA in 1958. This uniform code of the law of sales in trade relations among members of the Council for Mutual Economic Assistance has assimilated commercial arbitration tribunals in various socialist countries with domestic courts under a uniform legal system. Interest in a uniform practice of commercial arbitration is also strengthened by the fact that all government trading agencies, handling both export and import aspects of foreign trade, are in an identical situation and are vitally interested in the uniformity of foreign trade laws in their relations with all other socialist countries. ${ }^{37}$ Differing interpretations of the provisions of the General Conditions of Delivery, and for that matter of the unwritten law of commercial usage and custom, affect the efficiency of trade operations.

An illustration in point was provided by a case of conflicting interpretations of article 74 of the General Conditions of Delivery by the East German and Polish arbitration tribunals. Article 74 provided that: "Relations of parties to the delivery of goods, in so far as they are not regulated or not fully regulated by contracts, or by the present General Conditions, shall be governed by the substantive law of the seller's country." The Polish tribunal understood this provision as renvoi to the general provisions of the civil and commercial law in force, while their German colleagues thought that article 74 referred them to regulations governing contracts between the governmental enterprises. In effect, German commercial arbitration applied shorter terms of prescription and a stricter statute of limitations for the presentation of claims or counterclaims resulting from foreign trade transactions. This difficulty was referred to the ministers of foreign trade who resolved it by means of direct negotiations and who recommended the Polish practice as corresponding to the true sense of article $74^{38}$

In the general tendency toward uniform practice in the decisions of arbitral tribunals of the socialist countries an important role is played by Soviet arbitration commissions. Soviet practice is frequently quoted in the decisions of the national tribunals. The authority of Soviet know-how in matters of foreign trade, and the desire to establish practices in trade adjudication common for all countries of the

\footnotetext{
${ }^{37}$ Ishchenko \& Zacepin, Obshchye tuslovia SEV 1958 goda-dokument bolshogo znachenia, 1958 Vneshniata Torgovlia No. 12, at Io.

${ }^{38}$ ig6r Handel Zagraniczen No. 8, at 366-68; Kamper, Das subsidiar anwendbare in der Praxis des Schiedsgerichtes bei der Kammer fur Aussenhandel der DDR, I959 RECHT IM AUssentandeL No. 3/4, at 7-9; Kamper, Durch Vervollkommung der AB das $R G W$ zur endgultigen Losung der Frage des subsidiar anwendbaren Rechts, 1960 Recht IM Aussenhandel No. 4, at I-6; Jakubowski, Prawne ramy obrottl handlowego miedzy krajami socjalistycznymi, I96I Panstwo I PRAwo 536.
} 
socialist commonwealth, has found expression in the fact that Soviet arbitration commissions were on several occasions called upon to arbitrate in disputes between members of the bloc in which no Soviet interests were involved, thus furthering the unity and legal cohesion of the socialist commonwealth. This they could do because Soviet rules of procedure do not exclude their services in disputes between third parties. While the rules of other arbitral tribunals in principle make their services available to any country, within or without the bloc, only Soviet institutions have in practice handled disputes of this type in any volume. The influence of Soviet commercial arbitration is reminiscent of the role the supreme courts played in the national judiciary as contributors to the uniformity of legal practice and security of commerce. ${ }^{39}$

\footnotetext{
${ }^{39}$ Lunts, Voprosy mezhdunarodnogo chastnogo prava $v$ otnosheniakh mezhdu stranami mirovoi sotsialisticheskoi sistemy, 1959 Sovetski ERHegodnik Mezhdonarodnogo Prava (Soviet Yearbook of International Law) 65; Lunts lists disputes between Poland, Hungary, Bulgaria, and Czechoslovakia on the agenda of Soviet arbitration commissions; of. D. RAMZAITSEv, VNESHNETORGovyI ARBITRAZH v SSSR (I952); Keilen, $K$ zoretiv dejatelnosti morskoi arbitrazhnoi kommissii, I961 Vneshniain Torgovina No. 3, at 6-r2; Ramzaitsev, Voprosy mezhdunarodnogo chastnogo prava v praktikie uneshnetorgovoi arbitrazhnoi kommissii, 1957 Sovetskoe Gosodarstvo I Pravo No. 9, at 51.
} 